\title{
Reconsidering national identity through intermedial Latin American Studies: An interview with Richard Gordon ${ }^{1}$
}

Frans Weiser

Key words: adaptation, anthropophagy, Brazil, historical film, Latin America, social identity theory

Soletras - Both of your books deal with cinema from different angles, Cannibalizing the Colony (2009) examining the adaptation of foundational Latin American colonial texts while Cinema, Slavery, and Brazilian Nationalism (2015) utilizes social identity theory to explore the historical marginalized communities. Despite differing theoretical approaches, however, both works share a focus upon the impact of film upon audiences as well as conceptions of nation. What led to the evolution in your research? Has your understanding of cinema as a form of social influence changed over the course of researching the two works?

Back in the late 90s and early 2000s when I began investigating historical cinema in Latin America and the Caribbean I was struck by the massive number of films produced about the colonial period, especially in Mexico and Brazil. At first I thought I would find most of the films from around 1992 and 2000, the years that recognized the arrival of the Spanish and Portuguese to the Americas. After all, my interest in this topic started with the film Cabeza de Vaca, which came out in 1991 and repurposed a sixteenth-century narrative about the encounter to rethink critically the European colonial enterprise. While several interesting films did come out around that time, what I found was an intense and ongoing interest among filmmakers from the silent period through the present. To me this indicated a constant, continental interest in the past among those responsible for producing cinema, at least, and we can infer that this also implied some regular interest in the topic among audiences. Rather than costume dramas that allowed people to enjoy a brief, nostalgic escape into a former time, common in the history of English-language cinema, what I found in Brazil, Mexico, and also

\footnotetext{
${ }^{1}$ Richard Gordon is Professor of Brazilian and Spanish-American Literature and Culture as well as Director of the Latin American and Caribbean Studies Institute at the University of Georgia. His research focuses on historical film and social identity, specifically, the capacity for cinema to influence how people understand the social groups to which they belong. He has published two books, Cannibalizing the Colony: Cinematic Adaptations of Colonial Literature in Mexico and Brazil (Purdue University Press, 2009) and Cinema, Slavery, and Brazilian Nationalism (University of Texas Press, 2015), he is co-editing an upcoming Inter-American collection, Beyond Tordesillas: Critical Essays in Comparative Luso-Hispanic Studies.
} 
Cuba, for example, was a lingering preoccupation with issues in the past that have left their mark in the present, such as the interaction between the European colonizers and indigenous peoples and the African slavery in the Americas. My first book focused on the former issue and my second book on the latter. So I would say that I've retained an interest in this topic and over the years I've focused on different issues and looked at this social phenomenon from different angles. My work has evolved in the sense that it has become more interdisciplinary and more theoretical. I felt that with the tools available through the field of social psychology and work being done in the area of cognitive approaches to cinema, I would be more able in the second book to understand both how Brazilian films about slavery propose new ways of understanding Brazilianness and how these films might actually have an impact on the way that audiences think about themselves and others. In other words, I've always been interested in cinema (and television, of course) as a form of social influence, but it was more recently that I felt more equipped to explore this topic directly.

Soletras - Particularly noteworthy in Cannibalizing the Colony is the amount of space you dedicate to analyzing not only film adaptations of colonial texts during the twentieth century, but also the source texts themselves. You develop the term "anthropophagous adaptations" to describe the ways your case studies "dominate and digest their source" (51). Anthropophagy as a cultural strategy has been most closely associated with Brazil, but your Inter-American comparison suggests that this is a shared Latin American practice. Can you speak more to this textual-audiovisual relationship?

In that book I took advantage of Oswald de Andrade's modernist reconceptualization of anthropophagy as a strategy of cultural appropriation and empowerment to describe an approach to adaptation that took what we might call both poetic and political license. In other words, rather than privileging faithfulness to a source text the films that I studied freely manipulated the source texts in order to make whatever points they intended to make. Often they used texts produced by colonizers to criticize colonization. Therefore, because of the aggressive and liberal nature of the transformation of documents from the colonial period, and the topic and tenor of the texts and films themselves, anthropophagy as used by Andrade and many more afterwards in Brazil seemed an apt shorthand to describe these adaptations. Even though the concept of ritual cannibalism did not have in Mexico the same meaning as it did in 
Brazil, cinema certainly manifested a similar attitude toward the colonial past: instead of revering what might in other national contexts foundational texts, filmmakers consumed these textual vestiges of colonization and turned them into opportunities to think critically about the past and what it means for the present.

Soletras - Perhaps the most explicit form of anthropophagous adaptation you deal with occurs in Chapter Two, which analyzes cannibalism and captivity narratives in Nicolás Echevarría's Cabeza de Vaca (1991) and Nelson Pereira dos Santos' Como era gostoso o meu francês (1971). You argue that both films utilize complex strategies of simultaneously exoticizing indigenous characters while also making the audience identify with them in order to revise history in the present. Do you believe that this specific alterity/similarity relationship also characterizes the general process of adaptation in the present? Or, is the process of adaptation more abstract, given that you note how many audiences are unfamiliar with the source texts?

I think those two films strike a delicate balance in their representation of Europeans and indigenous peoples. Compared to other films — whether they be adaptations or films about the past that are not grounded in some kind of text - they are relatively rare in the tension they promote in terms of identification with the different groups. Often films about topics like colonization and slavery in Latin America and the Caribbean will be more explicit about who the "good guys" or "bad guys" were. But probably the best ones, and the ones that have more potential to influence audiences, have been, like the films you mention, more varied and nuanced in their representation of different social groups in order to make their point.

Soletras - Cinema, Slavery, and Brazilian Nationalism is more specifically concerned with the concept of Brazilianness as constructed through historical films about Afro-Brazilian historical figures, yet in this case the fact that the texts under consideration are films and not novels is important. In your experience, does cinema serve a distinct communicative function in comparison to written fiction? Can you speak to the filmic strategies that encourage viewers to reconsider their social identities? 
I think audio-visual narratives-film, and often to a greater degree, television programs such as soap operas - generally have a greater potential to influence society, but not in every instance. One factor is exposure, and I would guess that in Brazil, for example, greater numbers of people have seen a film or a novela about the colonial past or about slavery than have read novels about the same topics. However, it's true that some historical novels have been read more than some historical films. Another factor is how people interact with these different kinds of cultural artifacts. Film and television have at their disposal a wide array of tools to guide how people understand and engage emotionally with the stories they tell. Perhaps we can say that they leave less to the imagination than written narratives do. In many ways they show us rather than tell us. Of course, this is an over-simplification. In Cinema, Slavery, and Brazilian Nationalism I go into detail about ways that films potentially influence audiences. I don't compare them to novels, but I do treat cinema as a specific communicative medium.

Soletras - In your opinion, does social identity theory have implications in film scholarship for other or mainstream forms of belonging aside from nationalism, or, in the case of Brazil during the process of redemocritization, the critique of national belonging? Where do you think more scholarship needs to take place?

Absolutely. I've found research in social psychology, in particular Social Identity Theory, to be especially helpful in understanding and describing in detail the social dynamics that films often represent. I took my cue initially from Patrick Hogan's Understanding Nationalism. This book, and my book focus largely on one social group that often looms large in people's minds, the one defined by the nation where they are citizens, and how they and others understand that group, their opinion of what it stands for, its ideals, etc., and the stimuli-such as film - that can change their understanding of the group. However, the same research also helps us to understand how people think about other social groups that they are part of, such as ones defined by gender, religion, politics, etc. A nuanced perspective on the nature of social groups can help us describe and critique any number of different social situations or their representation, such as rejections of national belonging or resistance to propagandistic efforts to influence citizens to feel nationalistic pride. Such interdisciplinary 
approaches can help us to transcend traditional and often simplified ways of talking about "national identity".

Soletras - Your first two book-length studies have been comparative in terms of geographical scope and interdisciplinary approach, and the upcoming edited collection on comparative Luso-Hispanic Studies Beyond Tordesillas continues that trend. It seems that various connotations of adaptation serve as a thread that connects all three works, not only in the sense of literature-to-film adaptations, but also the role of adapting to and transforming one's surroundings within a social context. You are a strong proponent of interdisciplinary collaboration that blurs the lines between disciplines; by way of conclusion, where do you see collaboration playing a role in Brazilian and Latin American Studies from a perspective within the U.S. academy?

I don't think interdisciplinarity is unique to Latin American Studies, although area studies programs by their very nature encourage the intersection of all disciplines in terms of working together. I experience this on an administrative level, since I direct the Latin American and Caribbean Studies Institute at my university, and we have affiliates from every college on campus. In some ways I see this role is an extension of my own academic production; our institute acts as a nexus not only among areas at the university, but we also have increasingly established links between our interdisciplinary groups and colleagues in other countries in the Americas, something I see as the future of hemispheric partnerships.

\section{Repensando a identidade nacional através dos estudos latino-americanos intermédios: Uma entrevista com Richard Gordon}

Palavras-chave: adaptação, antropofagia, Brasil, filme histórico, América Latina, teoria da identidade social 